\title{
ASPEK WANPRESTASI BADAN PENYELENGGARA PERGURUAN TINGGI SWASTA DALAM HAL TIDAK MEMBAYARKAN KEKURANGAN UPAH DOSEN
}

\author{
Mhd. Erwin Munthe \\ STIE Syariah Bengkalis \\ Sungai Alam, Bengkalis Sub-District, Bengkalis Regency, Riau 28714, 0811-7501-025 \\ Email: bmtherwinmunthe@gmail.com
}

\begin{abstract}
In the implementation of work agreements between the two parties, it is not always successful in creating a harmonious working relationship. Often, there are disputes over rights in the form of wages. This research is normative legal research. The approach used is the statutory approach and the case approach. This study aims to find out how the legal relationship is formed between Private Universities (PTS) and Lecturers. Then that there is an act of default carried out by Private Universities (PTS) in terms of not paying wage shortages to Lecturers. The results of this study are first, the legal relationship (rechtverding) between Private Universities (PTS) and Lecturers is a working relationship based on mutual agreement (contractual). Second, the action in the form of not paying wage shortages to Lecturers is an act of default. So if it is disadvantaged, the Lecturer can sue the Private University (PTS) to request the implementation of the agreement as well as asking for compensation in the amount of the unpaid wages.
\end{abstract}

Keywords: Default, Wages, Work Agreement

\begin{abstract}
ABSTRAK
Dalam Pelaksanaan perjanjian kerja diantara kedua belah pihak tidak selalu berhasil menciptakan hubungan kerja yang harmonis.Seringkali diantara keduanya terjadi perselisihan hak berupa upah. Penelitian ini adalah penelitian hukum normatif. Pendekatan yang digunakan adalah pendekatan perUndang-Undangan (statute approach) dan pendekatan kasus (case approach). Penelitian ini bertujuan untuk mengetahui bagaimana hubungan hukum yang terbentuk antara Perguruan Tinggi Swasta (PTS) dan Dosen.. Kemudian bahwa ada tindakan wanprestasi yang dilakukan Perguruan Tinggi Swasta (PTS) dalam hal tidak membayarkan kekurangan upah kepada Dosen. Hasil dari penelitian ini adalah pertama, hubungan hukum (rechtverhouding) antara Perguruan Tinggi Swasta (PTS) dan Dosen merupakan hubungan kerja yang berdasar pada kesepakatan bersama (kontraktual). Kedua, tindakan berupa tidak membayarkan kekurangan upah kepada Dosen merupakan perbuatan wanprestasi. Maka apabila dirugikan Dosen dapat menuntut Perguruan Tinggi Swasta (PTS) untuk meminta pelaksanaan perjanjian sekaligus meminta ganti rugi sebesar upah yang tidak dibayarkan.
\end{abstract}

Kata Kunci: Wanprestasi, Upah, Perjanjian Kerja

\section{PENDAHULUAN}

Yayasan sejak awal sudah dikenalkan oleh Pemerintah Kolonial Belanda dengan sebutan "stichting”, yaitu sebuah badan hukum yang memiliki prinsip sebagai badan hukum yang kegiatannya bersifat non komersial $(\text { (nirlaba) })^{1}$ yang bergerak dibidang sosial, kegamaan ataupun pendidikan. Oleh karenanya tidak

\footnotetext{
1 Asas nirlaba atau non komersial adalah tidak mencari laba atau keuntungan. Artinya modal yayasan tidak diolah untuk memperoleh keuntungan, melainkan untuk melakukan kegiatan yang bermanfaat bagi masyarakat. Lihat Gatot Supramono, (2008), Hukum Yayasan di Indonesia, Jakarta: Rineka Cipta, hlm. 110.
} 
boleh menjalankan kegiatan dalam perbuatan hukum berbentuk apapun yang ditujukan untuk memperoleh keuntungan.

Landasan badan hukum yayasan selama ini hanya berdasarkan kebiasaan dalam masyarakat dan yurisprudensi, ${ }^{2}$ karena belum ada peraturan perundang-undangan yang mengatur tentang Yayasan. Ketidkadaan aturan hukum yang khusus mengenai yayasan mengakibatkan terjadinya berbagai penafsiran terkait misalnya status hukum, hakikat dan tujuan suatu yayasan serta aspek-aspek lain dalam pengelolaan yayasan. ${ }^{3}$ Akibatnya yayasan disalahgunakan dan menyimpang dari tujuan idilnya yang semula.

Pada tahun 2001 dibentuklah UndangUndang Nomor 16 Tahun 2001 tentang Yayasan dalam rangka memberikan jaminan kepastian hukum dan ketertiban hukum. Sehingga dengan berlakunya undang-undang ini dapat dipastikan yayasan merupakan suatu institusi yang berbadan hukum, dimana kekayaannya terpisah dan kekayaan tersebut hanya diperuntukkan ${ }^{4}$ untuk mencapai tujuan tertentu di bidang sosial, keagamaan, dan kemanusiaan, yang tidak mempunyai anggota. $^{5}$

Dalam maksud untuk mencapai tujuan yayasan yang bersifat nirlaba, maka Yayasan dapat melakukan kegiatan usaha dengan mendirikan Badan Penyelenggara Perguruan Tinggi Swasta. Perguruan Tinggi adalah satuan pendidikan yang menyelenggarakan Pendidikan Tinggi.

Pengaturan mengenai Perguruan Tinggi diatur di dalam Peraturan Pemerintah Nomor 4 Tahun 2014 tentang Penyelenggara Pendidikan Tinggi dan Pengelolaan Perguruan Tinggi. Di dalam Pasal 1 ayat 6 dijelaskan salah satu bentuk perguruan tinggi adalah Perguruan Tinggi Swasta (selanjutnya disingkat PTS).

PTS adalah Perguruan Tinggi yang didirikan dan/atau diselenggarakan oleh

2 Yayasan sebagai badan hukum telah diterima dalam suatu yurisprudensi tahun 1882. Hoge Raad yang merupakan badan peradilan tertinggi di negeri Belanda berpendirian bahwa yayasan sebagai badan hukum adalah sah menurut hukum dan karenanya dapat didirikan. Pendapat Hoge Raad ini diikuti oleh Hooggerechtshof di Hindia Belanda dalam putusannya dari tahun 1884. Pendirian Hoge Raad di negeri Belanda tersebut dikukuhkan dengan diundangkannya Wet op Stichting Stb. Nomor 327 Tahun 1956, yang kemudian pada Tahun 1976 Undang-undang tersebut disatukan ke dalam buku kedua Burgelijk Wetboek yang mengatur perihal tersebut disatukan ke dalam buku kedua Burgelijk Wetboek yang mengatur perihal badan hukum (buku kedua titel kelima Pasal 285 sampai dengan 305 BW Belanda). Yayaysan juga diatur dalam putusan Mahkamah Agung RI tanggal 27 Juni 1973 No.124 K/Sip/1973 memutuskan bahwa yayasan dapat disebut sebagai badan hukum sepanjang memenuhi unsur-unsur mempunyai harta kekayaan sendiri, mempunyai tujuan sendiri (tertentu), mempunyai alat perlengkapan.

3 Yetti Komalasari Dewi,dkk, (2003), Analisis Dan Evaluasi Peraturan Perundang-Undangan Tentang Yayasan, Jakarta: Pusat Perencanaan Pembangunan Hukum Nasional Badan Pembinaan Hukum Nasional Kementerian Hukum Dan HAM RI, hlm. 7.

4 Badan hukum merupakan pendukung hak dan kewajiban, sama seperti manusia pribadi. Setiap badan hukum memiliki kekayaan dan bertujuan untuk kepentingan tertentu, dan tujuan badan hukum adalah objek yang dilindungi oleh hukum. Lihat Abdulkadir Muhammad, (2006), Hukum Perusahaan di Indonesia, Bandung: Citra Aditya Bakti, hlm.101.

5 Lihat Pasal 1 UU No. 16 Tahun 2001 Tentang Yayasan. 
masyarakat. Adapun badan penyelenggara PTS di jelaskan di dalam Pasal 1 ayat 19 dapat berupa yayasan, perkumpulan atau badan hukum nirlaba sebagaimana diatur dalam ketentuan peraturan perundang-undangan. ${ }^{6}$ Untuk menyelenggarakan suatu pendidikan yang bermodel kan pendidikan tinggi, suatu perguruan tinggi tak lepas dari adanya tenaga pendidik yaitu sosok Dosen dan tenaga kependidikan yaitu pelaksana administrasi, pengelolaan, pengembangan, pengawasan, keamanan dan lain sebagainya. Didalam peraturan perundang-undangan dijelaskan bahwa Dosen memikul tugas dan amanah yang sangat fundamental dan signifikan dalam mencerdaskan kehidupan bangsa melalui pendidikan tinggi.

Hal ini dapat di lihat pada Pasal 1 angka 2 Undang-Undang No. 14 Tahun 2005 Tentang Guru dan Dosen jo Pasal 1 angka 14 UndangUndang No. 12 Tahun 2012 Tentang Pendidikan Tinggi jo Pasal 1 angka 1 Peraturan Pemerintah No. 37 Tahun 2009 Tentang Dosen, dimana "Dosen adalah pendidik profesional dengan tugas utama mentransformasikan, mengembangkan dan menyebarluaskan, teknologi dan seni melalui pendidikan, penelitian dan pengabdian kepada masyarakat". Dengan demikian profesi dosen merupakan profesi yang sangat mmebutuhkan profesionalitas.

Komitmen dalam melaksanakan perjanjian kontraktual antara Perguruan Tinggi Swasta (PTS) dan Dosen tidak selalu berhasil menciptakan hubungan yang harmonis. Seringkali diantara keduanya terjadi perselisihan hak.

Seperti kasus yang terjadi antara Lembaga Pendidikan dan Pelatihan "Khalifah Generasi Teladan" dengan beberapa tenaga pengajar nya di Taman Kanak-kanak TK Khalifah 22, dimana yayasan tidak membayarkan kekurangan upah dan uang pesangon kepada tenaga pengajar ketika tidak dipekerjakan lagi. $^{7}$

Hal yang sama terjadi di Banda Aceh dimana Pengadilan Hubungan Industrial Banda Aceh, mengabulkan sebagian gugatan Surya Murni terhadap Yayasan Ma'had Ulumuddin, karena diputuskan hubungan kerja secara sepihak sejak tanggal 23 Juni 2014 tanpa pemberian uang pesangon. ${ }^{8}$

Perguruan tinggi Universitas Gunung Leuser dimana puluhan dosen kontrak, pegawai fungsionaris, dekan fakultas sampai rektor beramai-ramai mengajukan pengunduran diri dari kampus dikarenakan yayasan pendidikan Universitas Gunung

7 __ (3/11/2014), Meskipun Bukan Berbentuk Perusahaan, Yayasan Dihukum Bayar Pesangon. diakses pada tanggal 17 April 2020, Buruhonline.com, https://buruh-online.com/2014/11/meskipun-bukan-berbentukperusahaan-yayasan-dihukum-bayar-pesangon.html.

$8 \ldots$ _ (27/4/2015), PHI Nyatakan Yayasan Termasuk Kualifikasi Perusahaan, Buruh Online.com, diakses pada tanggal 17 April 2020, https://buruh-online.com/2015/04/phi-nyatakan-yayasan-termasuk-kualifikasiperusahaan.html. 
Leuser belum membayarkan gaji selama satu tahun. ${ }^{9}$

Kejadian serupa juga terjadi kepada dosen di Universitas Nahdlatul Ulama Sulawesi Tenggara, dimana para dosen tidak dibayarkan gajinya selama 2 tahun. Padahal jelas didalam SK termuat hak dan kewajiban mereka mengenai gaji dan tunjangan yang harus dibayar oleh kampus ataupun yayasan setiap bulannya. ${ }^{10}$

Perselisihan dalam motif lain meskipun memiliki kemiripan juga banyak terjadi, dimana Badan Penyelenggara Perguruan Tinggi Swasta menjanjikan akan membayar seluruh kekurangan gaji selama pada akhir tahun atau pada awal tahun berikutnya. Hal ini dilakukan agar para dosen dan karyawan tidak mogok bekerja, mengundurkan diri, atau menuntut haknya melalui jalur hukum.

Berangkat dari hal tersebut, peneliti tertarik untuk mengkaji hubungan hukum (rechtverhouding) yang terbentuk antara Perguruan Tinggi Swasta (PTS) dan Dosen dalam hal pengupahan. Kemudian bagaimana teori wanprestasi melihat aktivitas Badan Penyelenggara Perguruan Tinggi Swasta (PTS) tidak membayarkan kekurangan upah kepada Dosen. Penelitian ini adalah penelitian hukum normatif atau biasa disebut dengan penelitian doktrinal. Penelitian doktrinal merupakan penelitian yang menyediakan ekspos sistematis terhadap peraturan yang mengatur kategori hukum tertentu, menganalisis hubungan antar peraturan dan menjelaskan area yang mengalami hambatan serta memperkirakan perkembangan mendatang. ${ }^{11}$ Pendekatan yang digunakan adalah pendekatan perundang-undangan (statute approach) dan dan pendekatan kasus (case approach).

\section{PEMBAHASAN}

Konsep Hubungan Hukum (Rechtverhouding)

\section{Dalam Ranah Perdata}

Hubungan hukum (rechtverhouding) secara doktrin dan normatif akan merujuk kepada hukum perikatan. Sebab hubungan hukum (rechtverhouding) dalam bidang

9 Jupri, (3/1/2019), Setahun gaji tak dibayar, Dosen dan Rektor UGL ramai-ramai mengundurkan diri, diakses tanggal 17 April 2020. Beritakini.com, https://beritakini.co/news/setahun-gaji-tak-dibayar-dosen-dan-rektorugl-ramai-ramai-mengundurkan-diri/index.html.

10 Ahmad Akbar Fua, (11/3/2020), Kisah Dosen Universitas di Sulawesi Tenggara Tak Terima Gaji Sejak tahun 2017, Liputan6.com., https://www.liputan6.com/regional/read/4198338/kisah-dosen-universitas-di-sulawesitenggara-tak-terima-gaji-sejak-2017.

11 Abdulkadir Muhammad, (2004), Hukum dan Penelitian Hukum, Cet. 1, Bandung: Citra Aditya Bakti, 2004), hlm. 52. 
perdata $^{12}$ merupakan bagian unsur-unsur ${ }^{13}$ yang melekat didalam perikatan. ${ }^{14}$

Hubungan hukum adalah hubungan yang diatur dan diakui oleh hukum. Hubungan hukum pada akhirnya akan menimbulkan akibat hukum. Didalam hubungan hukum, hubungan diatara kedua belah pihak yang didalamnya melekat hak pada satu pihak dan kewajiban pada pihak lainnya. Hak dan kewajiban ini dapat dipertahankan di hadapan pengadilan. ${ }^{15}$ Apabila hak dan kewajiban tidak dipenuhi dapat dikenakan sanksi. ${ }^{16}$

Salah satu bentuk hubungan hukum dalam bidang perdata ${ }^{17}$ adalah hubungan kerja. Hubungan kerja adalah perikatan yang terjadi antara pemberi kerja dan penerima kerja berdasarkan perjanjian. ${ }^{18}$ Perjanjian kerja (arbeidsovereenkomst) diatur dalam Pasal 1601 KUHPerdata yaitu perjanjian kerja adalah suatu perjanjian dimana pihak yang satu yaitu buruh, mengikatkan diri untuk bekerja pada pihak yang lain yaitu majikan, selama waktu tertentu dengan menerima upah. Perjanjian kerja ini menciptakan hukum yang bersifat "subdordinatif". Artinya, kedudukan hukum yang tidak setara, majikan (pengusaha) adalah atasan dan pekerja (pembantu pengusaha) adalah bawahan.

Lalu Husni mengatakan pemberlakuan Pasal diatas pertama kali di Indonesia pada saat zaman penjajahan Kolonial Belanda yang bercorak pada sistem perbudakan, rodi, dan peonale sanctie. ${ }^{19}$

Tiga tahun setelah Indonesia merdeka, Pemerintah mengeluarkan Undang-undang No.12 Tahun 1948 tentang Kerja dan saat ini pengaturan mengenai hubungan kerja diatur dalam Undang-undang No. 13 Tahun 2003 tentang Ketenagakerjaan (selanjutnya disebut Undang-Undang Ketenagakerjaan). Undang-

12 Perdata atau hukum perdata menurut subekti adalah hukum yang mengatur hubungan antar manusia yang satu dengan yang lain dengan menitikberatkan pada kepentingan perseorangan. Lihat buku C.S.T Kansil dan Christine S.T. Kansil, (__ ), Pokok-pokok pengetahuan hukum dagang indonesia, Jakarta: Sinar grafika, Cet. Ke-5, hlm. 5.

13 Berdasarkan pengertian perikatan yang dibangun para pakar hukum diatas, dapat ditarik kesimpulan bahwa terdapat unsur-unsur yang melekat didalam perikatan yaitu: hubungan hukum (rechtsverhouding, legal relationship), Kekayaan (vermogen, patrimonial), Para pihak (partijen, parties), Prestasi (prestatie, performance). Ridwan Khairandy, (__ $)$, Hukum Kontrak Indonesia Dalam Perspektif Perbandingan Yogyakarta: FH UII Press, Cet. Ke-2, hlm. 6-8.

14 Subekti mengemukakan bahwa perikatan adalah hubungan hukum mengenai harta kekayaan antara dua orang atau lebih dimana pihak yang satu berhak menuntut sesuatu dari pihak yang lain dan pihak lainnya diwajibkan memenuhi tuntutan itu. Ibid, hlm. 5.

15 Ibid, hlm. 7.

16 Abdul Kadir Muhammad, (2000), Hukum Perdata Indonesia, Bandung: citra Aditya Bakti, 2000, hlm.2.

17 Subekti mengatakan bahwa hukum perdata dalam arti luas meliputi semua hukum "private materiil", yaitu segala pokok yang mengatur kepentingan-kepentingan perseorangan. Wirjono Prodjodikoro mengatakan bahwa hukum perdata sebagai suatu rangkaian hukum antara orang-orang atau badan hukum satu sama lain mengatur tentang hak dan kewajiban dalam pergaulan kemasyarakatan mereka. Lihat I Ketut Oka Setiawan, (2016), Hukum Perorangan dan Kebendaan, Jakarta: Sinar Grafika, 2016, hlm. 2-3.

18 AbdulKadir Muhammad, Op.cit., hlm. 33.

19 Susilo Andi Darma, (__ Juni 2017), Kedudukan Hubungan Kerja : Berdasarkan Sudut Pandang Ilmu Kaidah Hukum Ketenagakerjaan Dan Sifat Hukum Publik Dan Privat, Mimbar Hukum, Volume 29, Nomor 2, hlm. 222. 
Undang Ketenagakerjaan sebagai hukum khusus (lex specialis) dari hukum KUHPerdata (legi generalis).

Undang Undang Ketenagakerjaan merupakan hukum publik yang disebabkan sosialisering proses. Akan tetapi dalam pengaturan hal kerja masih dapat ditemukan adanya ketentuan-ketentuang yang sifatnya privat. $^{20}$

Hubungan kerja di dalam Undang-Undang Ketenagakerjaan di atur dalam Pasal 50 Undang-Undang Ketenagakerjaan. Hubungan kerja adalah hubungan yang terjadi karena adanya perjanjian kerja antara pengusaha dengan pekerja. Sementara perjanjian kerja di dalam Pasal 1 ayat 14 di jelaskan bahwa perjanjian kerja adalah perjanjian antara pekerja/buruh dengan pengusaha atau pemberi kerja yang memuat syarat syarat kerja, hak, dan kewajiban para pihak. Perjanjian kerja ini setidak-tidaknya mengandung empat unsur yaitu adanya pekerjaan, adanya upah dan adanya perintah.

M.G Rood ${ }^{21}$ pakar hukum perburuhan dari Belanda menambahkan satu unsur yaitu:

a. Adanya unsur pekerjaan (work)

Dalam suatau perjanjian kerja haruslah ada pekerjaan yang jelas yang dilakukan oleh pekerja dan sesuai dengan yang tercantum dalam perjanjian yang telah disepakati dengan ketentuan-ketentuan yang tercantum dalam UU No.13 Tahun 2003 tentang Ketenagakerjaan.

b. Adanya perintah/dibawah perintah (gezag ver houding)

Perjanjian Kerja mengandung unsur penunaian kerja, dimana satu pihak akan menunaikan atau melaksanakan kerja dari pihak lain. Yang tersangkut dalam Perjanjian Kerja adalah manusianya yang akan menunaikan/melaksanakan kerja tersebut.

c. Adanya unsur waktu (time)

Bahwa terikatnya seorang pekerja dalam Perjanjian Kerja mempunyai jangka waktu. Jangka waktu Perjanjian Kerja dibedakan menjadi dua, yaitu jangka waktu tertentu dan jangka waktu tidak tertentu. Perjanjian Kerja jangka waktu tertentu atau Perjanjian Kerja untuk karyawan kontrak biasanya satu tahun, dapat diperpanjang satu kali lagi. Dan dalam keadaan tertentu merupakan Perjanjian Kerja untuk karyawan tetap, akan berakhir apabila terjadi PHK, baik karena pensiun, mengundurkan diri, dipecat, atau meninggal dunia.

d. Adanya unsur upah (pay)

Upah adalah hak pekerja/buruh yang diterima dan dinyatakan dalam bentuk uang sebagai imbalan dari pengusaha

20 Ibid, hlm. 223

21 Basani Situmorang, dkk., (2010), Laporan Pengkajian Hukum Tentang Menghimpun Dan Mengetahui Pendapat Ahli Mengenai Pengertian Sumber-Sumber Hukum Mengenai Ketenagakerjaan, Jakarta: Badan Pembinaan Hukum Nasional Departemen Hukum Dan HAM, hlm. Xvi. 
atau pemberi kerja kepada pekerja/buruh yang ditetapkan dan dibayarkan menurut suatu perjanjian kerja, kesepakatan, atau peraturan perundang undangan, termasuk tunjangan bagi pekerja/buruh dan keluarganya atas suatu pekerjaan dan/atau jasa yang telah atau akan dilakukan.

Perjanjian kerja dapat tertulis maupun lisan hal ini dinyatakan di dalam Pasal 51 ayat 1 Undang-Undang Ketenagakerjaan. Kemudian di dalam ayat 2 dinyatakan bahwa perjanjian kerja yang disyaratkan secara tertulis dilaksanakan sesuai dengan peraturan perundang-undangan yang berlaku.

Kemudian di dalam Pasal 63 ayat 1 dinyatakan bahwa untuk perjanjian kerja dalam bentuk lisan untuk perjanjian kerja waktu tidak tertentu (PKWTT) mewajibkan pengusaha untuk membuat surat pengangkatan.

Jika diperhatikan pernyataan Pasal 63 ayat 1 Undang-Undang Ketenagakerjaan diatas, maka menurut ketentuan dan kebiasaan yang berlaku hubungan kerja yang terbentuk antara Perguruan Tinggi Swasta (PTS) dan Dosen berdasar pada perjanjian lisan untuk Perjanjian Kerja waktu Tidak Tertentu. Oleh karenanya menjadi suatu kewajiban bagi Badan Penyelenggara Perguruan Tinggi Swasta untuk membuat surat pengangkatan.

\section{Hubungan Kerja Antara Dosen Dan Badan Penyelenggara Perguruan Tinggi Swasta (PTS)}

Pengangkatan Dosen pada Badan Penyelenggara Perguruan Tinggi atau Satuan Pendidikan Tinggi diatur di dalam Pasal 36 ayat (2) Peraturan Pemerintah No. 37 Tahun 2009 Tentang Dosen (Selanjutnya disebut PP No.37 Tahun 2009) disebutkan bahwa "Pengangkatan dan penempatan dosen pada satuan pendidikan tinggi yang diselenggarakan oleh masyarakat dilakukan oleh penyelenggara pendidikan atau satuan pendidikan tinggi yang bersangkutan berdasarkan perjanjian kerja atau kesepakatan kerja bersama". ${ }^{22}$ Ketentuan tersebut diatas menjelaskan bahwa isi dari hubungan kerja antara Dosen dan Perguruan Tinggi Swasta (PTS) diatur dalam perjanjian kerja yang telah disepakati bersama. Adapun bentuk perjan Bentuk perjanjian kerja antara Dosen dan Perguruan Tinggi Swasta (PTS) atau Satuan Pendidikan Tinggi lebih lanjut diatur di dalam Pasal 1 angka 9 PP No. 37 Tahun 2009 bahwa “perjanjian kerja atau kesepakatan kerja bersama merupakan perjanjian tertulis antara Dosen dengan penyelenggara pendidikan atau satuan pendidikan yang memuat syarat-syarat kerja serta hak dan kewajiban para pihak dengan prinsip kesetaraan dan kesejawatan berdasarkan peraturan perundang-

22 Lihat Pasal 63 Ayat (3) Undang-undang No. 14 Tahun 2005 Tentang Guru dan Dosen, Lihat juga Pasal 69 ayat (2) Undang-Undang No. 12 Tahun 2012 Tentang Pendidikan Tinggi. 
undangan". ${ }^{23}$ Bentuk perjanjian kerja diatas memungkin adanya dua bentuk perjanjian kerja yaitu PKWT untuk dosen tidak tetap atau dosen kontrak dan PKWTT untuk dosen tetap. Untuk dosen tetap bentuk . dari perjanjian kerjanya adalah dengan dikeluarkannya surat pengangkatan dosen oleh Yayasan yang membawahi Badan Penyelenggara Perguruan Tinggi Swasta tersebut.

Adapun mengenai pengupahan dosen diatur di dalam pada Pasal 70 angka 3 Undang-Undang Nomor 12 Tahun 2012 jo Peraturan Pemerintah Republik Indonesia Nomor 37 Tahun 2009 bahwa Badan penyelenggara wajib memberikan gaji pokok serta tunjangan kepada Dosen dan tenaga kependidikan sesuai dengan ketentuan peraturan perundang-undangan.

Berdasarkan penjelasan diatas, dapat disimpulkan hubungan hukum yang terbentuk antara Dosen dan Perguruan Tinggi Swasta (PTS) adalah hubungan kerja yang berdasar pada perjanjian kerja. . Baik perjanjian kerja tersebut lahir karena adanya kesepakatan diantara keduanya maupun lahir karena perintah Undang-Undang Ketenagakerjaan.

Tindakan Wanprestasi Badan Penyelenggara Perguruan Tinggi Swasta (PTS) Kepada Dosen Atas Kekurangan Upah Yang Tidak Dibayarkan
Dalam konsep hukum perikatan ${ }^{24}$ dijelaskan bahwa salah satu unsur perikatan adalah prestasi (prestatise). Prestasi adalah adalah kewajiban yang harus dipenuhi oleh seorang debitor. Istilah lain dari prestasi ini adalah utang. Utang bermakna sebagai kewajiban yag harus dipenuhi debitor. Debitor sendiri adalah orang yang melakukan suatu prestasi dalam suatu perikatan.

Didalam kontrak atau perjanjian, prestasi adalah kewajiban kontraktual (contractual obligation). Kewajiban kontraktual tersebut dapat berasal dari:

1. Kewajiban yang ditentukan peraturan perundang-undangan.

2. Kewajiban yang diperjanjikan para pihak dalam perjanjian atau kontrak.

3. Kewajiban yang diharuskan oleh kepatutan dan kebiasaan.

Di dalam Pasal 1234 KUHPerdata dinyatakan bentu-bentuk prestasi yaitu memberikan sesuatu, melaksanakan sesuatu dan tidak berbuat atau tidak melaksanakan sesuatu.

Di dalam perjanjian kerja, pekerja memiliki kewajiban untuk melakukan sesuatu pekerjaan tertentu. Dalam posisi ini, pekerja berkedudukan sebagai debitor. Majikan atau pengusaha juga memiliki kewajiban untuk memberikan upah kepada karyawan. Dalam hal ini majikan atau pengusaha juga

\footnotetext{
23 Lihat Pasal 1 angka 7 Undang-undang No. 14 Tahun 2005 Tentang Guru dan Dosen, lihat juga Pasal 1 angka 9 Peraturan Pemerintah N0. 37 Tahun 2009 Tentang Dosen.

24 Ridwan Khairandy, Op.Cit, hlm.269.
} 
194 Yurispruden Volume 3, Nomor 2, Juni 2020, Halaman 186-199.

berkedudukan sebagai debitor. ${ }^{25}$ Pada kesalahan dalam arti luas, yakni berupa umumnya hak dan kewajiban yang lahir dari kesengajaam (opzet) atau kealfaan perjanjian dipenuhi oleh pihak-pihak baik (onachtzaamheid). Dalam arti sempit debitur maupun kreditur. Akan tetapi dalam kesalahan hanya bermakna kesengajaan. praktek kadang-kadang debitur tidak Kesalahan dalam wanprestasi adalah mematuhi apa yang menjadi kewajibannya kesalahan yang menimbulkan kerugian bagi dan inilah yang disebut dengan kreditor. Perbuatan berupa wanprestasi "wanprestasi". 26

Wanprestasi atau cidera janji adalah suatu kondisi dimana debitor tidak melaksankan kewajiban yang ditententukan perikatan, khususnya perjanjian (kewajiban kontraktual). Wanprestasi dapat juga terjadi dimana debitor tidak melaksanakan kewajibannya yang ditentukan didalam Undang-undang.

Tidak terpenuhinya kewajiban itu ada dua kemungkinan alasannya yaitu: ${ }^{27}$ Suatu kewajiban itu tidak terpenuhi kemungkinan disebabkan oleh dua alasan yaitu:

1. Karena kesalahan debitor, baik karena kesengajaan maupun karena kelalaian.

2. Karena keadaan memaksa (force majeure, overmacht), sesuatu yang terjadi diluar kemampuan debitor, debitor tidak bersalah.

Dalam hal wanprestasi karena kesalahan (schuld) debitor, yakni tidak melaksanakan kewajiban kontraktual yang seharusnya tersebut menimbulkan kerugian terhadap kreditor, dan perbuatan itu harus dapat dipersalahkan kepada debitor. Kerugian tersebut harus dapat dipersalahkan kepada debitor, jika unsur kesengajaan atau kelalaian dalam persitiwa yang menimbulkan kerugian pada diri kreditor dan dapat dipertanggungjawabkan pada debitor. Kerugian yang diderita kreditor tersebut dapat berupa biaya-biaya (ongkos-ongkos) yang telah dikeluarkan kreditor, kerugian yang menimpa harta benda milik kreditor, atau hilangnya keuntungan yang diharapkan. ${ }^{28}$

Undang-Undang tidak mengatur soal ganti rugi yang timbul dari perbuatan wanprestasi. Oleh karena itu, aturan yang dipakai dalam persoalan yang timbul adalah Pasal 1267 KUHPerdata. Didalam Pasal 1234 KUHPerdata memerinci ganti rugi biaya (konsten), kerugian (schade) dan bunga (interesten). Adapun besaran ganti ruginya adalah sesuai dengan upah Dosen yang diperjanjikan dalam ditunaikan. Kesalahan tersebut adalah

\footnotetext{
25 Ibid, hlm. 272.

${ }^{26}$ I ketut Oka Setiawan, Hukum Perikatan (Jakarta: Sinar Grafika, 2017, Cet. Ke-2), hlm. 19.

27 Ibid, hlm. 278

28 Ibid, hlm. 281.
} 
perjanjian kerja atau surat keterangan prosedur penyelesaian perselisihan hubungan pengangkatan dosen tetap oleh yayasan.

Undang-undang Ketenagakerjaan secara implisit menjelaskan wanprestasi bagian dari perselisihan hubungan industrial. Karena terkait dengan perselisihan atau perbedaan pendapat mengenai hak upah yang terdapat dalam perjanjian kerja. Di dalam Pasal 1 angka 22 di jelaskan bahwa Perselisihan hubungan industrial adalah perbedaan pendapat yang mengakibatkan pertentangan antara pengusaha atau gabungan pengusaha dengan pekerja/buruh atau serikat pekerja/serikat buruh karena adanya perselisihan mengenai hak, perselisihan kepentingan, dan perselisihan pemutusan hubungan kerja serta perselisihan antar serikat pekerja/serikat buruh hanya dalam satu perusahaan.

Pasal 136 ayat 1 Undang-Undang Ketenagakerjaan menentukan bahwa dalam hal terjadi perselisihan antara pengusaha dengan pekerja maka penyelesaian hubungan industrial wajib dilaksanakan secara musyawarah untuk mufakat. Ayat 2 menyatkan bahwa dalam hal penyelesaian secara musyawarah untuk mufakat sebagaimana dimaksud dalam ayat (1) tidak tercapai, maka pengusaha dan pekerja/ buruh atau serikat pekerja/serikat buruh menyelesaikan perselisihan hubungan industrial melalui industrial yang diatur dengan undang-undang.

Dengan demikian berdasarkan kerangka teori perbuatan wanprestasi diatas, maka persoalan mengenai tidak dibayarkannya kekuarangan upah dosen oleh Perguruan Tinggi Swasta (PTS) baik dengan sengaja maupun karena kelalian dapat digolongkan kepada perbuatan wanprestasi, sebab menurut M. Yahya wanprestasi adalah pelaksanaan kewajiban yang tidak tepat pada waktunya atau melakukan tidak menurut selayaknya. Meijers menyatakan bahwa wanprestasi adalah perbuatan yang tidak melaksanakan kewajiban yang timbul dari perjanjian. ${ }^{29}$

Perjanjian kerja adalah perjanjian perjanjian tertulis antara dosen dengan penyelenggara perguruan tinggi yang memuat syarat-syarat kerja serta hak dan kewajiban para pihak dengan prinsip kesetaraan dan kesejawatan berdasarkan peraturan perundang-undangan. ${ }^{30}$

Jika merujuk pada ketentuan UndangUndang Ketenagakerjaan dikatakan perjanjian kerja apabila terdapat komponen pekerjaan, perintah /dibawah perintah (gezag ver houding) dan upah. Adanya komponen "pekerjaan" menjelaskan bahwa dosen memeiliki tugas sebagai tenaga pendidik yang bertugas mentransformasikan, mengembangkan, dan menyebarluaskan ilmu pengetahuan,

\footnotetext{
29 Ibid, hlm. 279.

30 Pasal 1 angka 9 PP No. 37 Tahun 2009 Tentang Dosen
} 
teknologi, dan seni melalui pendidikan, penelitian, dan pengabdian kepada masyarakat. Seorang Dosen apabila statusnya merupakan Dosen tetap maka ia bekerja penuh waktu yang berstatus sebagai tenaga pendidik tetap pada satuan pendidikan tinggi tertentu.

Kemudian komponen "perintah /dibawah perintah (gezag ver houding)"jika dikaitkan dengan Pasal 36 ayat (2) PP No. 37 Tahun 2009 maka kata-kata "perintah" dapat dipersamakan dengan istilah pengangkatan sekaligus penempatan Dosen pada Perguruan Tinggi Swasta (PTS).. Adanya pengangkatan pengangkatan sekaligus penempatan Dosen oleh Perguruan Tinggi Swasta (PTS) menjadi langkah awal untuk Dosen menunaikan kewajiban-kewajibannya sesuai dengan bentuk perjanjian kerja apakah bentuknya Perjanjian Kerja Waktu Tertentu atau Perjanjian Waktu Kerja tidak Tertentu atau dalam istilah lain sebagai Dosen tetap atau Dosen tidak tetap. Komponen "upah" dapat disamakan dengan gaji, yaitu suatu hak yang diterima oleh dosen atas pekerjaannya dari penyelenggara pendidikan tinggi atau Satuan Pendidikan Tinggi dalam bentuk finansial secara berkala sesuai dengan peraturan perundang-undangan. ${ }^{31}$ Dalam dunia ketenagakerjaan upah merupakan sumber utama penghasilan seorang dosen. Sebab itu upah harus cukup untuk memenuhi kebutuhan dosen dan keluarganya dengan wajar. Kenyataan menunjukkan bahwa hanya sedikit pengusaha yang sadar dan terus-menerus berusaha meningkatkan penghidupan karyawannya, hal ini bagi pengusaha upah dapat dipandang sebagai beban, karena semakin besar upah yang dibayarkan kepada pekerja, semakin kecil proporsi keuntungan bagi pengusaha. Padahal jika ditelaah lebih dalam karyawan merupakan aset penting bagi kemajuan dan pengembangan suatu perusahaan terlebih jika karyawan tersebut memiliki produktivitas yang tinggi. ${ }^{32}$ tuKomponen "waktu". Di dalam doktrin dan pendapat pakar komponen waktu merupakan bagian dari unsur perjanjian kerja. Adanya unsur waktu berkaitan dengan jangka waktu bekerja. Jika dikaitkan dengan Pasal 48 ayat 1 Undang-undang No. 14 Tahun 2005 Tentang Dosen jo Pasal 1 angka 2 Peraturan Pemerintah No. 37 Tahun 2009 Tentang Dosen jo Pasal 9 Peraturan Menteri Pendidikan dan Kebudayaan No. 84 Tahun 2013 Tentang Pengangkatan Dosen Tetap Non PNS pada PTN dan Dosen Tetap pada PTS, maka status dosen terdiri atas dosen tetap dan dosen tidak tetap. Dosen tetap bekerja penuh waktu sedangkan Dosen tidak tetap bekerja paruh waktu. Dosen yang diangkat sebagai dosen tetap memiliki

31 Pasal 1 angka 6 Peraturan Pemerintah Nomor 37 Tahun 2009 Tentang Dosen.

32 Payaman J. Simanjuntak, (1996), Pengantar Ekonomi Sumber Daya Manusia, Jakarta: Lembaga Penerbit Fakultas Ekonomi UI, hlm. 131-132. 
kewajiban untuk bekerja penuh selama 40 (empat puluh) jam per minggu dan wajib melaksanakan Tridharma Perguruan Tinggi. Ketentuan mengenai waktu kerja dalam Undang-Undang Ketenagakerjaan diatur di dalam Pasal 77 ayat (1) dan (2) yaitu waktu kerja sebagaimana dimaksud dalam ayat (1) meliputi 7 (tujuh) jam 1 (satu) hari dan 40 (empat puluh) jam 1 (satu) minggu untuk 6 (enam) hari kerja dalam 1 (satu) minggu atau 8 (delapan) jam 1 (satu) hari dan 40 (empat puluh) jam 1 (satu) minggu untuk 5 (lima) hari kerja dalam 1 (satu) minggu.

Justifikasi bahwa Bahwa Badan Penyelenggara Pergruan Tinggi Swasta melakukan perbuatan wanprestasi dapat dilihat dari unsur-unsur yang dikemukakan para ahli: ${ }^{33}$

1. Tidak melakukan apa yang disanggupi akan dilakukannya

Hal ini dapat dilihat dari tidak dilaksanakannya isi perjanjian kerja yang tertera pada surat keterangan pengangkatan Dosen tetap atau surat keputusan yayasan mengenai hak dan kewajiban dosen.

2. Melaksanakan apa yang diperjanjikan, tetapi tidak sebagaimana yang diperjanjikan

Badan Penyelenggara Perguruan Tinggi Swasta memberikan upah tetapi tidak sesuai dengan besaran upah yang terdapat di dalam perjanjian kerja atau pada surat keterangan pengangkatan Dosen tetap atau surat keputusan yayasan mengenai hak dan kewajiban dosen. Dosen seringkali tidak menerima kekurangan upah yang diperjanjikan karena dengan alasan keuangan Badan Penyelenggara Perguruan Tinggi Swasta tidak mencukupi untuk membayar kekurangan tersebut.

3. Melakukan apa yang diperjanjikan tetapi terlambat

Permasalahan keterlambatan Badan Penyelenggara Perguruan Tinggi Swasta dalam membayar upah Dosen seringkali terjadi. Padahal kewajiban dosen dalam menjalankan tugasnya tetap dilakukan. Tetapi kurang operasional Badan Penyelenggara Perguruan Tinggi Swasta seringkali membuat upah Dosen terlambat diberikan. Dan menurut peneliti untuk denda keterlambatan sangat jarang difirkan oleh intitusi tersebut.

4. Melakukan sesuatu yang menurut perjanjian tidak boleh dilakukan.

Badan Penyelenggara Perguruan Tinggi Swasta melakukan kesalahan (schuld) kepada Dosen yaitu tidak membayarkan kekurangan upah dosen baik dengan kesengajaan (opzet) ataupun karena kealfaan (onachtzaamheid).

33 Ridwan Khairandy, Op.Cit, hlm..280. 
198 Yurispruden Volume 3, Nomor 2, Juni 2020, Halaman 186-199.

Sebagaimana dijelaskan diatas, maka pengabdian kepada masyarakat, maka dalam hal adanya wanprestasi yang dilakukan kewajiban Perguruan Tinggi Swasta (PTS) oleh Badan Penyelenggara Pergruan Tinggi Swasta kepada Dosen mengenai kekurangan upah yang tidak dibayarkan, maka menurut peneliti seorang Dosen dapat menuntut haknya berupa meminta pelaksanaan perjanjian sekaligus meminta ganti rugi sebagaimana ketentuan Pasal 1267 KUHPerdata. Seorang dosen dapat menuntut hak nya berupa kekurangan upah yang tidak dibayarkan sesuai dengan besaran upah yang terdapat di dalam perjanjian kerja dan/atau besaran upah minimum sesuai perintah undang-undang.

\section{KESIMPULAN}

Pasal 36 ayat (2) Peraturan Pemerintah No. 37 Tahun 2009 mengatur bagaimana pengangkatan sekaligus penempatan Dosen pada satuan pendidikan tinggi yang diselenggarakan oleh Badan Penyelenggara Perguruan Tinggi Swasta berdasarkan perjanjian kerja atau kesepakatan kerja. Dengan adanya pengangkatan dan penempatan berarti hubungan hukum yang terjadi antara kedua belah pihak adalah hubungan privat berupa hubungan kerja yang bersifat kontraktual, artinya masing-masing pihak terikat untuk melaksankan hak dan kewajiban masing-masing. Dengan demikian jika Dosen telah menunaikan kewajibannya sebagai tenaga profesional yaitu melaksanakan Tridharma Perguruan Tinggi berupa mengajar, melakukan penelitian serta adalah memberikan upah.

Dalam hal Badan Penyelenggara Perguruan Tinggi Swasta tidak melakukan kewajiban kontraktual sesuai dengan isi perjanjian (wanprestasi) baik itu karena kesalahan (schuld) atau kelafaan atau kelalaian (onachtzaamheid). Misalnya tidak membayarkan kekurangan upah Dosen, maka Dosen dapat menuntut haknya berupa meminta Badan Penyelenggara Perguruan Tinggi agar menunaikan kewajibannya berupa membayar ganti rugi(schade) sesuai yang tertulis dalam surat perjanjian kerja dan sesuai perintah Undang-Undang Ketenagakerjaan.

\section{SARAN}

Konsekuensi adanya hubungan kerja mengharuskan Perguruan Tinggi Swasta (PTS) dan Dosen untuk mematuhi dan mengindahkan asas-asas perjanjian seperti asas pacta sun servanda, asas itikad baik, dan asas konsensualisme. Jika hal ini tidak dapat dilaksankan oleh Badan Penyelenggara Perguruan Tinggi Swasta, penulis menyarankan agar Ketua/Rektor pada instansi tersebut kiranya dapat mengundurkan diri dari jabatannya. Kemudian diharuskan bagi Badan Penyelenggara Perguruan Tinggi Swasta tetap membayarkan kekurang upah kepada dosen sebagaimana mestinya dengan cara mencarikan dana dari pihak ketiga sambil memberikan pemahamana kepada Dosen tentang keadaan keuangan kampus. 


\section{DAFTAR PUSTAKA}

\section{Buku}

Abdulkadir Muhammad, 2006, Hukum Perusahaan di Indonesia, Bandung: PT. Citra Aditya Bakti.

Abdulkadir Muhammad, 2004, Hukum dan Penelitian Hukum, Cet. 1, Bandung: PT. Citra Aditya Bakti.

Abdul Kadir Muhammad, 2000, Hukum Perdata Indonesia, Bandung: citra Aditya Bakti.

C.S.T Kansil dan Christine S.T. Kansil, 2010, Pokok-pokok pengetahuan hukum dagang indonesia, Cet. Ke-5, Jakarta: Sinar grafika.

Gatot Supramono, 2008, Hukum Yayasan di Indonesia, Jakarta: Rineka Cipta.

I Ketut Oka Setiawan, 2016, Hukum Perorangan dan Kebendaan, Jakarta: Sinar Grafika.

Ridwan Khairandy, 2014, Hukum Kontrak Indonesia Dalam Perspektif Perbandingan (Bagian Pertama), Yogyakarta: FH UII Press.

\section{Jurnal/Artikel/Penelitian}

Basani Situmorang, dkk. Laporan Pengkajian Hukum Tentang Menghimpun Dan Mengetahui Pendapat Ahli Mengenai Pengertian Sumber-Sumber Hukum Mengenai Ketenagakerjaan, Badan Pembinaan Hukum Nasional Departemen Hukum Dan HAM, 2010.

Devirly Juwita Putri Cahyono dan Dipo Wahyono, Penyelesaian Perselisihan Antara Badan Penyelenggara Perguruan Tinggi Swasta Dengan Dosen, Mimbar Keadilan Jurnal Ilmu Hukum Februari, 2017.

Susilo Andi Darma, Kedudukan Hubungan Kerja: Berdasarkan Sudut Pandang Ilmu Kaidah Hukum Ketenagakerjaan Dan Sifat Hukum Publik Dan Privat, 2017, Mimbar Hukum Volume 29, Nomor 2.

Yetti Komalasari Dewi,dkk, Analisis Dan Evaluasi Peraturan PerundangUndangan Tentang Yayasan, Pusat Perencanaan Pembangunan Hukum Nasional Badan Pembinaan Hukum
Nasional Kementerian Hukum Dan HAM RI, 2013.

\section{Peraturan Perundang-undangan}

Undang-Undang No. 13 Tahun 2013 Tentang Ketenegakerjaan

Undang-Undang No. 2 Tahun 2004 Tentang Penyelesaian Perselisihan Hubungan Industrial

Undang-Undang No. 1 Tahun 2001 Tentang Yayasan

Undang-undang Nomor 28 Tahun 2004 Tentang Perubahan Atas UndangUndang Nomor 16 Tahun 2001 Tentang Yayasan

Undang-Undang No. 14 Tahun 2005 Tentang Guru dan Dosen

Undang-Undang No. 12 Tahun 2012 Tentang Pendidikan Tinggi

Peraturan Pemerintah No. 37 Tahun 2009 Tentang Dosen

Peraturan Pemerintah No. 4 Tahun 2014 Tentang Penyelenggaraan Perguruan Tingi dan Pengelolaan Perguruan Tinggi

Permendikbud No. 84/2013 Tentang Pengangkatan Dosen Tetap Non PNS pada PTN dan Dosen Tetap pada PTS.

Kitab Undang-Undang Hukum Perdata

\section{Website/Internet}

Buruh Online.com, Meskipun Bukan Berbentuk Perusahaan, Yayasan Dihukum Bayar Pesangon. Diakses pada tanggal 17 April 2020

Buruh Online.com , PHI Nyatakan Yayasan Termasuk Kualifikasi Perusahaan, Diakses pada tanggal 17 April 2020

Beritakini.com, Setahun gaji tak dibayar, Dosen dan Rektor UGL ramai-ramai mengundurkan diri, diakses tanggal 17 April 2020.

Liputan6.com, Kisah Dosen Universitas di Sulawesi Tenggara Tak Terima Gaji Sejak tahun 2017. 